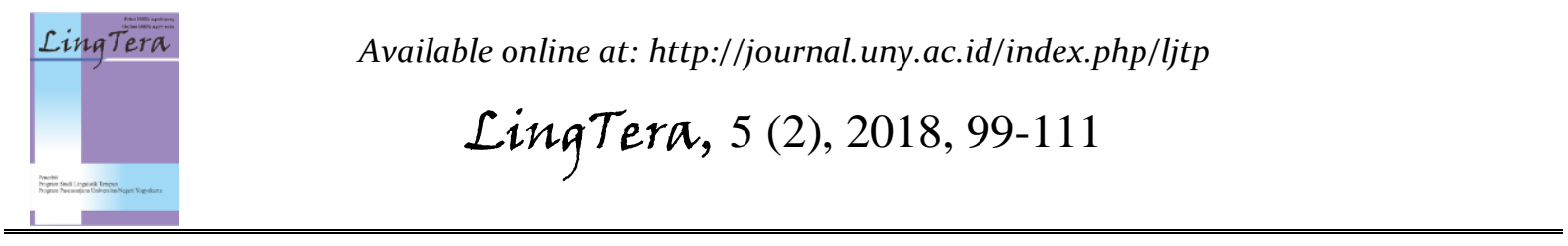

\title{
Bahasa kasar dialek Banyumasan
}

\author{
Dimas Setiaji Prabowo *, Mulyana Mulyana \\ Program Studi Pendidikan Bahasa Jawa, Program Pascasarjana, Universitas Negeri Yogyakarta \\ Jalan Colombo No. 1, Yogyakarta, 55281, Indonesia \\ * Corresponding Author. Email: dimasprabowo803@yahoo.co.id \\ Received: 6 January 2018; Revision: 6 August 2018; Accepted: 25 December 2018
}

\begin{abstract}
Abstrak
Penelitian ini bertujuan untuk menjelaskan bahasa kasar Dialek Banyumasan di Desa Kedungreja Kabupaten Cilacap. Penelitian ini menjelaskan wujud, referen, dan fungsi bahasa kasar Dialek Banyumasan. Penelitian ini adalah penelitian deskriptif. Sumber data dari penelitian ini yaitu tuturan lisan masyarakat Desa Kedungreja Kabupaten Cilacap dalam kegiatan sehari-hari di tempat yang banyak terjadi proses interaksi dari para penuturnya. Langkah-langkah pengumpulan data dari penelitian ini yaitu dengan cara teknik menyimak, teknik sadap, teknik rekam, dan teknik catat. Teknik analisis data yang digunakan dalam penelitian ini adalah dengan cara teknik analisis sosio pragmatik. Untuk mendapatkan validitas data dengan menggunakan validitas triangulasi teori, validitas semantik, dan pertimbangan ahli, sedangkan untuk mendapatkan reliabilitas menggunakan reliabilitas stabilitas. Hasil penelitian ini menjelaskan tentang wujud, referen, dan fungsi bahasa kasar Dialek Banyumasan di Desa Kedungreja Kabupaten Cilacap. Wujud bahasa kasar Dialek Banyumasan di Desa Kedungreja Kabupaten Cilacap yaitu kata dasar, kata berimbuhan, dan frasa. Referensi bahasa kasar Dialek Banyumasan di Desa Kedungreja Kabupaten Cilacap yang ditemukan meliputi referen nama hewan, bagian tubuh, jenis makanan, kata benda, kotoran, keadaan seseorang, keadaan tertentu, dan kegiatan tertentu. Fungsi bahasa kasar dialek Banyumasan di Desa Kedungreja Kabupaten Cilacap digunakan untuk menjelaskan rasa marah, rasa jengkel, rasa kecewa, menghina orang lain, rasa menyesal, dan rasa heran.
\end{abstract}

Kata Kunci: bahasa kasar, dialek Banyumasanan, Desa Kedungreja Kabupaten Cilacap

\section{Harsh language of Banyumasan dialect}

\begin{abstract}
The aim of this research was to explain the coarse language of Banyumasan dialect in Kedungreja village, Cilacap Regency. This study explained form, reference, and function of the coarse Language of Banyumasan dialect. This study is descriptive research. The data of the research was the coarse words of Banyumasan dialect in Kedungreja Village, Cilacap Regency. The steps of gathering data for this research were observing technique, tapping technique, recording, and writing the data of research. The technique of data analysis in this research was sociopragmatic analysis technique. This study applied validity triangulation theory, semantic validity, and expert consideration to get data validity, while to get reliability, it implied reliability stability. The result of this research is a description about form, reference, and function of the coarse language of Banyumasan dialect in Kedungreja Village, Cilacap Regency. The forms of the coarse Language of Banyumasan dialect in Kedungreja Village, Cilacap Regency were basic words, affixes, and phrases. The types of the course language of Banyumasan dialect in Kedungreja village, Cilacap Regency, were namely noun/noun phrases, adjectiveladjective phrases, and verb /verb phrases. The references of the coarse language of Banyumasan dialect in Kedungreja Village, Cilacap Regency were animal's name, parts of the body, type of food, noun, filth, someone's condition, certain condition, and certain activity. The function of the course language of Banyumasan dialect in Kedungreja Village, Cilacap Regency, was namely to express anger, irritation, disappointment, insulting others, regret and astonishment.
\end{abstract}

Keywords: coarse language, Banyumasan dialect, Kedungreja Village Cilacap Regency.

How to Cite: Prabowo, D., \& Mulyana, M. (2018). Bahasa kasar dialek Banyumasan. LingTera, 5(2), 99-111. doi:https://doi.org/10.21831/lt.v5i2.17819

https://doi.org/10.21831/lt.v5i2.17819 


\section{LingTera, 5 (2), 2018 - 100}

\section{Dimas Setiaji Prabowo, Mulyana Mulyana}

\section{PENDAHULUAN}

Masyarakat adalah sekumpulan orang yang sudah lama hidup berdampingan dan saling tolong menolong, sehingga dapat membuat sebuah organisasi yang dapat menumbuhkan rasa bahwa mereka adalah satu kesatuan social (Effendy, 1998). Di dalam organisasi tersebut tentunya terjadi proses interaksi dan pola tingkah laku yang khusus dan rasa identitas individu terhadap kelompoknya. Dalam proses interaksi, tentunya membutuhkan alat sebagai penunjang proses komunikasi, yaitu bahasa (Wicaksono, 2016). Bahasa adalah sistem simbol bunyi yang arbitrer, yang digunakan oleh masyarakat pengguna bahasa untuk membantu proses interaksi dan identifikasi (Devianty, 2017; Suhendi, 2017; Suherman, 2012).

Sebagai alat komunikasi, bahasa adalah sarana untuk menjelaskan tujuan hati, menumbuhkan rasa, yang nantinya kita juga akan mengerti apa yang diinginkan orang lain. Syarat utama dalam proses komunikasi adalah menguasai bahasa yang digunakan oleh masyarakat pengguna bahasa tersebut. Ketika seseorang telah menguasai bahasa yang berkembang dalam masyarakat, secara otomatis dia juga telah mengetahui perihal budaya yang berkembang dalam masyarakat. Penelitian ini dilaksanakan di salah satu daerah yang menggunakan dialek Banyumasan sebagai bahasa utama dalam kehidupan sehari-hari, yaitu di Desa Kedungreja Kabupaten Cilacap.

Penelitian ini tidak hanya membahas tentang satuan bahasa saja, akan tetapi juga penggunaannya di tengah-tengah masyarakat. Ilmu yang mempelajari tentang bahasa dan penggunaannya dalam masyarakat yaitu sosiolinguistik. Dalam sosiolinguistik, banyak sekali cabangcabang ilmu yang dipelajari, salah satunya yaitu variasi bahasa. Variasi bahasa jika dilihat dari segi penuturnya dibagi ke dalam 4 jenis, antara lain idiolek, dialek, kronolek, dan sosiolek. Dalam penelitian ini akan dibahas tentang dialek.

Dialek adalah variasi bahasa dari sekumpulan orang yang jumlahnya relatif dalam suatu wilayah (Junaidi, Yani, \& Rismayeti, 2016). Dialek digunakan sebagai ciri-ciri darimana asal orang tersebut, walaupun setiap individu mempunyai idiolek sendiri-sendiri, tetapi mempunyai unsur yang sama, yaitu dialek. Menurut salah satu ahli bahasa yang berasal dari Belanda, Uhlenbeck (1964), dialek yang digunakan di sebelah barat Jawa Tengah sebagai sekumpulan bahasa Jawa sisi barat (Banyumas, Kebumen, Purwokerto,
Cilacap, Purbalingga, Brebes, Tegal, Cirebon dan Banten sebelah utara). Wilayah Banyumasan dibagi menjadi dua bagian, yaitu Banyumasan sebelah utara meliputi, Brebes, Tegal, dan Pemalang, dan Banyumasan sebelah selatan yang meliputi Cilacap, Kebumen, Banjarnegara, Purbalingga, dan Banyumas.

Penelitian ini dilaksanakan di suatu wilayah yang menggunakan dialek Banyumasan sebagai bahasa keseharian masyarakatnya, yaitu di Desa Kedungreja Kabupaten Cilacap. Masyarakat Desa Kedungreja yang menggunakan dialek Banyumasan sebagai bahasa keseharian dikenal mempunyai ciri-ciri yang khusus, yaitu 'thok melong'. 'Thok melong yaitu peristilahan masyarakat Banyumasan yaitu berbicara apa adanya antara lahir dan batin tidak ada yang ditutup-tutupi. Kenyataan tersebut menyebabkan masyarakat awam mengira bahwa masyarakat dalek Banyumasan ketika berbicara dianggap kasar. Padahal mereka berbicara seperti itu ksrens sudah merupakan ciri khas yang sudah mendarah daging sejak dulu. Masyarakat awam kurang bisa membedakan mana bahasa normal dialek Banyumasan dan mana yang termasuk ke dalam bahasa kasar.

Sama halnya seperti dialek lainnya, dialek Banyumasan juga mempunyai bahasa kasar yang menjadi ciri khas mereka. Kenyataan tersebut terjadi akibat dari masyarakat yang heterogen yang dipengaruhi oleh berbagai faktor diantaranya faktor ekonomi, budaya, kedudukan sosial, lingkungan sekitarnya dan lain-lain. Bahasa kasar biasanya diucapkan oleh orang dengan strata sosial rendah. Masyarakat dengan strata sosial rendah cenderung bergaul dengan rakyat bawahan yang mana dalam hal penguasaan bahasa, mereka kurang memperhatikan aspek unggahungguh.

Penggunaan bahasa seseorang juga dipengaruhi oleh lingkungan sekitar seseorang tersebut tinggal. Masyarakat yang tinggal di lingkungan keraton tentu saja berbeda dengan masyarakat yang tinggal di daerah sekitar terminal atau pasar yang cenderung lebih kasar. Permasalahan tersebut dipengaruhi oleh terbatasnya ilmu pengetahuan yang dimiliki khususnya yang berkaitan dengan unggah-ungguh bahasa. Selain itu, masyarakat dengan tingkat ekonomi rendah juga lebih cenderung menggunakan bahasa kasar dalam pergaulan sehari-hari.

Bahasa kasar sering digunakan oleh masyarakat penutur Desa Kedungreja Kabupaten Cilacap. Bahasa kasar di Desa Kedungreja Kabupaten Cilacap dapat dilihat di tempat-tempat yang 
banyak terjadi proses interaksi diantara para penuturnya. Tempat-tempat yang sering dijumpai bahasa-bahasa kasar diantaranya di poskamling, daerah lingkungan pasar, tempat anak-anak muda mencari hiburan misalnya dandut, rental playstation, menonton pertandingan sepakbola dan lain-lain.

Wujud bahasa kasar dialek Banyumasan di Desa Kedungreja Kabupaten Cilacap diantaranya kata dasar, kata berimbuhan dan frasa. Referen bahasa kasar dialek Banyumasan di Desa Kedungreja Kabupaten Cilacap sama dengan dialek lainnya, contohnya referen nama hewan, jenis makanan, profesi, keadaan tertentu, keadaan seseorang, kotoran dan lain lain. Fungsi bahasa kasar dialek Banyumasan di Desa Kedungreja Kabupaten Cilacap, yaitu untuk menjelaskan rasa marah, rasa kecewa, rasa jengkel, lain sebagainya.

Cara menentukan kasar atau tidak kasar yaitu dengan menggunakan empat aspek, yaitu aspek yang pertama berkaitan dengan aspek diksi, puntuasi, konstruk kalimat, dan yang terakhir adalah konteks tuturan. Dilihat dari aspek diksi, banyak sekali kata-kata dialek Banyumasan yang dianggap kasar. Yang dimaksud kasar, yaitu mempunyai asosiasi negatif menurut masyarakat pengguna bahasa tersebut. Akan tetapi, walaupun misalnya dalam suatu tuturan, jika dilihat dari aspek diksi itu sudah kasar, tetap saja harus melihat konteks tuturan tersebut. Karena bisa saja diksi yang dianggap kasar, menjadi tidak kasar karena digunakan oleh penuturnya untuk bercanda sehingga merekatkan persaudaraan dengan mitra tuturnya. Contoh dari diksi yang dianggap kasar di Desa Kedungreja diantaranya, mbadhog, nyaplok, dan seterusnya.

Penentuan kasar atau tidak kasar juga dilihat dari aspek pungtuasi. Aspek pungtuasi berkaitan dengan intonasi dan lagu tuturan yang disimbolkan dengan tanda baca. Secara umum, tuturan dianggap kasar karena menggunakan intonasi tinggi, karena dilihat dari modus konvensional berupa kalimat perintah. Jika dilihat dari aspek konstruk, cara menentukan kasar atau tidak kasar dengan melihat kesantunan dalam berbahasa. Bahasa kasar di Desa Kedungreja Kabupaten Cilacap jika dilihat dari aspek konstruk, bahwa semakin panjang tuturan, maka semakin santun juga tuturan tersebut, akan tetapi semakin pendek tuturan tersebut, maka tuturan tersebut dianggap tidak dapat memenuhi kriteria kesantunan bahasa, karena dianggap kasar.

Dari semua aspek yang mempengaruhi suatu tuturan dianggap kasar atau tidak kasar, nantinya tetap saja dikaitkan dengan aspek utama yang digunakan untuk menentukan tuturan tersebut kasar atau tidak kasar, yaitu aspek konteks tuturan. Misalnya saja, dalam sebuah tuturan, dilihat dari diksi, tuturan tersut kasar, akan tetapi menjadi tidak kasar setelah dikaitkan dengan konteks tuturannya, seperti contoh berikut:

Sopir: "Yen arep mbadhog kae lo, njaluk karo ibune.. bar iki dhewe langsung lanjut neng Semarang, aku tak ngisi ban serep sik".

Kernet: "Yowis mas gampang ngko"

Percakapan tersebut jika dilihat dari konteks tuturan, terjadi di terminal bus antara sopir dan kernet bus. Walaupun dalam percakapan tersebut, ada kata ' mbadhog yang diucapkan oleh sopir kepada kernetnya yang sebenarnya jika dilihat dari aspek diksi termasuk kasar, akan tetapi dalam konteks tersebut, si kernet tidak marah kepada sopir. Kenyataan tersebut disebabkan antara sopir dan kernetnya tersebut merupakan teman yang akrab dan konteks tersebut juga terjadi dalam ragam santai.

Maka dari itu, cara menganalisis data yang telah didapatkan saat pengambilan data, harus dengan melihat 4 aspek penentu kasar atau tidak kasar sebuah tuturan, yaitu diksi, pungtuasi, konstruk kalimat, dan konteks kalimat yang merupakan aspek utama penentu kekasaran sebuah tuturan. Seperti contoh tuturan di bawah ini.

Konteks:

Ada sekumpulan anak muda yang sedang menonton pertandingan sepakbola di televise.

A: "Lengob banget sumpah, gari shoting thok koh!"

B: "Lah wong koe pada, Liverpool ditonton ya maraih odhole kaku...

Tuturan 'lengob' dalam percakapan tersebut berupa kata dasar jenis kata sifat. Referen yang digunakan dalam tuturan di atas yaitu referen keadaan seseorang. Menurut konteks tuturan tersebut di atas, diksi 'lengob' termasuk kasar, karena merujuk pada keadaan seseorang atau sifat seseorang yang sangat bodoh. Jika dilihat dari aspek pungtuasi, tuturan tersebut disampaikan dengan nada dan intonasi tinggi yang terbukti dengan adanya tanda seru sebagai wujud rasa kecewa. Jika dilihat dari aspek konstruk kalimat, tuturan di atas disampaikan dengan konstruk pendek, sehingga tuturan tersebut tidak dapat memenuhi kriteria kesantunan berbahasa. Kemudian jika dilihat dari aspek konteks tuturan, tembung 'lengob' oleh tokoh A digunakan untuk menjelaskan rasa kecewa kepada pemain bola 


\section{LingTera, 5 (2), 2018 - 102}

Dimas Setiaji Prabowo, Mulyana Mulyana

yang terlalu lama ketika menendang bola. Maka dari itu, dapat diambil kesimpulan, bahwa tembung 'lengob' dalam konteks di atas termasuk kasar.

Perlunya masalah ini diteliti adalah untuk menambah wawasan pembaca tentang dialek Banyumasan yang masih asing untuk masyarakat umum. Permasalahan tersebut diteliti juga sebagai pembanding bahasa kasar dialek Banyumasan dengan bahasa kasar dialek lainnya. Ketika mendengar masyarakat Desa Kedungreja yang berbicara dengan dialek Banyumasan terlihat seperti sedang marah, akan tetapi belum tentu sedang marah, karena harus melihat konteks pembicaraannya. Permasalahan tersebut dipengaruhi oleh masyarakat umum yang masih menilai bahwa orang yang berbicara dengan dialek Banyumasan itu selalu dianggap kasar.

\section{METODE}

Penelitian ini termasuk jenis penelitian deskriptif. Penelitian deskriptif dilakukan dengan cara observasi, menjelaskan, dan mengumpulkan data berdasarkan keadaan yang terjadi apa adanya seperti di lapangan (Dulock, 1993).

Data dari penelitian ini yaitu data yang bersifat lisan, yaitu bahasa kasar dialek Banyumasan di Desa Kedungreja Kabupaten Cilacap yang berwujud kata-kata dan frasa. Kemudian sumber data menurut Moleong (2013) menjelaskan bahwa sumber data utama dalam penelitian deskriptif berupa kata-kata. Sumber data dari penelitian ini adalah tuturan masyarakat Desa Kedungreja Kabupaten Cilacap. Dalam keseharian.

Teknik pengumpulan data dalam penelitian ini meliputi teknik menyimak, teknik sadap, teknik rekam, dan teknik menulis. Dalam teknik menyimak, peneliti melihat dan memperhatikan tuturan bahasa kasar dialek Banyumasan di Desa Kedungreja Kabupaten Cilacap. Proses tersebut dilakukan untuk menemukan kata-kata kasar dialek Banyumasan di Desa Kedungreja Kabupaten Cilacap. Teknik selanjutnya adalah teknik sadap yang dilakukan bersamaan dengan teknik menyimak. Teknik menyimak dilaksanakan bersamaan dengan teknik sadap (Sudaryanto, 1993; Yuliawan, 2016). Supaya data tersebut tidak hilang, bersamaan dengan teknik menyimak dan teknik sadap, peneliti harus merekam tuturantuturan bahasa kasar tersebut, supaya data dari penelitian ini tidak hilang. Kemudian proses terakhir yaitu teknik catat. Teknik catat merupakan proses transkripsi data yaitu dari yang berwujud rekaman kemudian disalin menjadi data yang berwujud tulisan.
Data penelitian ini merupakan data lisan, sehingga ketika pengumpulan data, agar data tidak hilang, maka data tersebut direkam dengan alat perekam yaitu handphone berbasis android. Kemudian untuk proses memasukkan data yang pertama menggunakan instrumen pengumpulan data yaitu berupa tabel analisis yang dibantu dengan kartu data.

Setelah data dikumpulkan, proses selanjutnya adalah teknik analisis data. Analisis data adalah proses interaktif, ketika data diteliti dan dianalisis dengan sistematis untuk menggambarkan kejadian yang ada (Noble \& Smith, 2014) Teknik analisis yang digunakan dalam penelitian ini adalah analisis sosiopragmatik. Penelitian ini menggunakan validitas triangulasi teori, validitas semantik dan pertimbangan ahli, sedangkan reliabilitas dalam penelitian ini menggunakan reliabilitas stabilitas.

\section{HASIL DAN PEMBAHASAN}

\section{Bahasa Kasar Berwujud Kata Dasar}

Bahasa kasar dialek Banyumasan di Desa Kedungreja Kabupaten Cilacap yang pertama wujudnya berupa kata dasar. Bahasa kasar berwujud kata dasar diantaranya terdapat beberapa referen yang digunakan yaitu, referen nama hewan, jenis makanan, pekerjaan, kotoran, bagian tubuh, keadaan seseorang, keadaan tertentu, dan kegiatan tertentu. Dan fungsi untuk menjelaskan rasa marah, kecewa, heran, menghina, menyesal, dan jengkel.

Berikut ini, contoh bahasa kasar dialek Banyumasan yang berwujud kata dasar dengan referensi nama hewan, untuk menjelaskan rasa kecewa.

Konteks:

Mas Bian kecewa karena salah satu pemainnya mengulangi kesalahannya lagi ketika bermain playstation sepakbola.

“Asu banget pindo kaya kiye baen!'.. (Rek 5/5Agsts17/00.03)

Kata 'asu' dalam konteks tersebut jika dilihat dari aspek referensial merujuk pada nama hewan tertentu. Hewan 'asu' dalam kehidupan masyarakat Jawa pada umumnya dan masyarakat Desa Kedungreja khususnya mengandung asosiasi negatif. Jika dilihat dari aspek diksi, kata ' $a s u$ ' tidak tergolong salah satu kata yang mengandung kasar. Akan tetapi, jika dilihat dari aspek pungtuasi, tuturan tersebut termasuk kasar, karena menggunakan nada tinggi dan tanda seru sebagai wujud rasa kecewa. Dilihat dari aspek konstruksi kalimat, tuturan tersebut diucapkan 
dengan konstruk pendek, sehingga tidak dapat memenuhi kriteria kesantunan bahasa. Begitu juga, jika dilihat dari aspek konteks, tuturan tersebut termasuk kasar, karena digunakan untuk menjelaskan rasa kecewa dari penuturnya.

Berikut ini, contoh bahasa kasar dialek Banyumasan yang berwujud kata dasar dengan referensi jenis makanan, untuk menghina orang lain.

Konteks:

Pak Urip menghina wanita yang memakai baju warna hitam, karena badannya terlihat besar seperti gethuk.

"Walah kae apa sing klambi ireng, awak kaya gethuk koh diomong ayu!"

(Rek 8/13Agsts17/ 22.54)

Kata 'gethuk' dalam konteks tersebut jika dilihat dari aspek referensial merujuk pada jenis makanan tertentu yang dibuat dari bahan ketela. Jika dilihat dari aspek diksi, kata 'gethuk' tidak tergolong kasar. Akan tetapi, jika dilihat dari aspek pungtuasi, tuturan tersebut termasuk kasar, karena menggunakan nada tinggi dan tanda seru sebagai wujud penghinaan terhadap orang lain. Dilihat dari aspek konstruksi kalimat, tuturan tersebut diucapkan dengan konstruk pendek, sehingga tidak dapat memenuhi kriteria kesantunan bahasa. Begitu juga, jika dilihat dari aspek konteks, tuturan tersebut termasuk kasar, karena digunakan untuk menghina orang lain.

Di Desa Kedungreja Kabupaten Cilacap, ada juga bahasa kasar dialek Banyumasan yang berwujud kata dasar dengan referensi jenis makanan, untuk menjelaskan rasa heran.

Konteks:

Mas Kiki merasa heran, karena hanya mendapatkan nilai 5 saja ketika sedang bermain kartu.

"Asem, malah ulih lima thok!"

(Rek 12/13Agsts17/ 23.33)

Kata 'asem' dalam konteks tersebut jika dilihat dari aspek referensial merujuk pada jenis makanan tertentu. Buah 'asem' merupakan nama buah yang rasanya asam dan biasanya digunakan untuk tambahan bumbu masak. Jika dilihat dari aspek diksi, kata 'asem' tidak tergolong kasar. Akan tetapi, jika dilihat dari aspek pungtuasi, tuturan tersebut termasuk kasar, karena menggunakan nada tinggi dan tanda seru sebagai wujud rasa heran. Dilihat dari aspek konstruksi kalimat, tuturan tersebut diucapkan dengan konstruk pendek, sehingga tidak dapat memenuhi kriteria kesantunan bahasa. Begitu juga, jika dilihat dari aspek konteks, tuturan tersebut terma- suk kasar, karena digunakan untuk menje-laskan rasa heran dari penutur kepada mitra tuturnya.

Bahasa kasar dialek Banyumasan yang berwujud kata dasar dengan referensi pekerjaan dengan fungsi untuk menghina orang lain.

Konteks:

Mas Boni bertanya kepada Pak Tarsim tentang pekerjaan orang tua Mba Surmi, Pak Tarsim menjawab, bahwa pekerjaan orang tua Mba Surmi itu gentho.

Mas Boni: "Mbok Anake wong nduwe?"

$$
\text { Pak Tarsim: "Gentho!" }
$$

(Rek18/ 27Agsts17/ 22.52)

Kata 'gentho' dalam konteks tersebut jika dilihat dari aspek referensial merujuk pada jenis pekerjaan atau profesi tertentu yaitu orang yang suka bermain judi. Profesi 'gentho' dalam kehidupan masyarakat Desa Kedungreja Kabupaten Cilacap memiliki asosiasi negatif. Jika dilihat dari aspek diksi, kata 'gentho' tergolong kata kasar. Jika dilihat dari aspek pungtuasi, tuturan tersebut termasuk kasar, karena menggunakan nada tinggi dan tanda seru sebagai wujud penghinaan kepada orang lain. Dilihat dari aspek konstruksi kalimat, tuturan tersebut diucapkan dengan konstruk pendek, sehingga tidak dapat memenuhi kriteria kesantunan bahasa. Begitu juga, jika dilihat dari aspek konteks, tuturan tersebut termasuk kasar, karena digunakan untuk menghina orang lain dalam konteks tersebut yaitu orang tua Mba Surmi.

Bahasa kasar dialek Banyumasan yang berwujud kata dasar dengan referensi kotoran dengan fungsi untuk menjelaskan rasa kecewa kepada orang lain.

Konteks:

Mas Bowo kecewa karena pemainnya kurang keras ketika menendang bola saat Mas Bowo sedang bermain playstation.

"Alah jan kopet! Kurang seru koh".

(Rek 5/5Agsts17/ 00.03)

Kata 'kopet' dalam konteks tersebut jika dilihat dari aspek referensial merujuk pada kotoran manusia. Kata 'kopet' dalam kehidupan masyarakat Desa Kedungreja Kabupaten Cilacap memiliki asosiasi negatif. Jika dilihat dari aspek diksi, kata 'kopet' tergolong kata kasar. Jika dilihat dari aspek pungtuasi, tuturan tersebut termasuk kasar, karena menggunakan nada tinggi dan tanda seru sebagai wujud rasa kecewa. Dilihat dari aspek konstruksi kalimat, tuturan tersebut diucapkan dengan konstruk pendek, sehingga tidak dapat memenuhi kriteria kesantunan bahasa. Begitu juga, jika dilihat dari aspek 


\section{LingTera, 5 (2), 2018 - 104}

\section{Dimas Setiaji Prabowo, Mulyana Mulyana}

konteks, tuturan tersebut termasuk kasar, karena digunakan untuk menjelaskan rasa kecewa kepada pemain bola yang cara menendang bolanya kurang keras.

Bahasa kasar dialek Banyumasan yang berwujud kata dasar dengan referensi bagian tubuh tertentu dengan fungsi untuk menjelaskan rasa marah.

Konteks:

Mas Ical marah karena saat dia memancing sudah lama, tetapi baru mendapatkan satu ikan.

"Lah kaya gathel pancen! mancing kit mau kur ulih siji jan".

(Rek 31/11Sept17/ 09.30)

Kata 'gathel' dalam konteks tersebut jika dilihat dari aspek referensial merujuk pada bagian tubuh organ intim laki-laki bagian kepala. Kata 'gathel' dalam kehidupan masyarakat Desa Kedungreja Kabupaten Cilacap memiliki asosiasi negatif. Jika dilihat dari aspek diksi, kata ' $g a t h e l$ ' tergolong kata kasar. Jika dilihat dari aspek pungtuasi, tuturan tersebut termasuk kasar, karena menggunakan nada tinggi dan tanda seru sebagai wujud rasa marah kepada orang lain. Dilihat dari aspek konstruksi kalimat, tuturan tersebut diucapkan dengan konstruk pendek, sehingga tidak dapat memenuhi kriteria kesantunan bahasa. Begitu juga, jika dilihat dari aspek konteks, tuturan tersebut termasuk kasar, karena digunakan untuk menjelaskan rasa marah.

Bahasa kasar dialek Banyumasan yang berwujud kata dasar dengan referensi keadaan seseorang dengan fungsi untuk menjelaskan rasa kecewa.

Konteks:

Mas Bian membuat kesimpulan bahwa yang sering melakukan kesalahan itu beknya semua, saat dia bermain playstation sepakbola.

"Kiye tah bek ke sing goblog kiye wil!"

(Rek 5/5Agsts17/00.03)

Kata 'goblog' dalam konteks tersebut jika dilihat dari aspek referensial merujuk pada keadaan seseorang yang sangat bodoh. Kata 'goblog' dalam kehidupan masyarakat Desa Kedungreja Kabupaten Cilacap memiliki asosiasi negatif. Jika dilihat dari aspek diksi, kata 'goblog' tergolong kata kasar. Jika dilihat dari aspek pungtuasi, tuturan tersebut termasuk kasar, karena menggunakan nada tinggi dan tanda seru sebagai wujud rasa kecewa kepada orang lain. Dilihat dari aspek konstruksi kalimat, tuturan tersebut diucapkan dengan konstruk pendek, sehingga tidak dapat memenuhi kriteria kesantunan bahasa. Begitu juga, jika dilihat dari aspek konteks, tuturan tersebut termasuk kasar, karena digunakan untuk menjelaskan rasa kecewa.

Bahasa kasar dialek Banyumasan yang berwujud kata dasar dengan referensi keadaan seseorang dengan fungsi untuk menjelaskan rasa heran.

Konteks:

Pak Sarimin bercerita bahwa dulu mempunyai pengalaman saat di hutan, bahwa anjing hutan jika digeber motor itu tidak takut, akan tetapi justru terlihat akan menggonggong.

"Montore digeber-geber ya mentheleng thok!'. (Rek 21/27Agsts 17/ 23.44)

Kata 'mentheleng' dalam konteks tersebut jika dilihat dari aspek referensial merujuk pada keadaan seseorang yang ketika melihat tidak mau berkedip. Kata 'mentheleng' dalam kehidupan masyarakat Desa Kedungreja Kabupaten Cilacap memiliki asosiasi negatif. Jika dilihat dari aspek diksi, kata 'mentheleng' tergolong kata kasar. Jika dilihat dari aspek pungtuasi, tuturan tersebut termasuk kasar, karena menggunakan nada tinggi dan tanda seru sebagai wujud rasa heran. Dilihat dari aspek konstruksi kalimat, tuturan tersebut diucapkan dengan konstruk pendek, sehingga tidak dapat memenuhi kriteria kesantunan bahasa. Begitu juga, jika dilihat dari aspek konteks, tuturan tersebut termasuk kasar, karena digunakan untuk menjelaskan rasa heran.

Bahasa kasar dialek Banyumasan yang berwujud kata dasar dengan referensi keadaan seseorang dengan fungsi untuk menjelaskan rasa jengkel.

Konteks:

Mas Bian kecewa kepada pemainnya karena saat bermain playstation sepakbola, karena di suruh shooting terlalu lama..

"Lengob banget sumpah! gari dishooting thok koh malah".

(Rek 23/6Sept17/17.30)

Kata 'lengob' dalam konteks tersebut jika dilihat dari aspek referensial merujuk pada keadaan seseorang yang tidak bisa apa-apa, gampang bingung dan kurang pintar. Kata 'lengob' dalam kehidupan masyarakat Desa Kedungreja Kabupaten Cilacap memiliki asosiasi negatif. Jika dilihat dari aspek diksi, kata 'lengob' tergolong kata kasar. Jika dilihat dari aspek pungtuasi, tuturan tersebut termasuk kasar, karena menggunakan nada tinggi dan tanda seru sebagai wujud rasa jengkel. Dilihat dari aspek konstruksi kalimat, tuturan tersebut diucapkan dengan konstruk pendek, sehingga tidak dapat memenuhi kriteria kesantunan bahasa. Begitu 
juga, jika dilihat dari aspek konteks, tuturan tersebut termasuk kasar, karena digunakan untuk menjelaskan rasa jengkel.

Bahasa kasar dialek Banyumasan yang berwujud kata dasar dengan referensi keadaan tertentu dengan fungsi untuk menjelaskan rasa menyesal.

Konteks:

Pak Indro menyesal karena sudah melakukan kesalahan saat mengluarkan kartunya saat bermain kartu.

"Aduh ya kiye remuk kiye!"

(Rek 7/13Agsts17/22.44)

Kata 'remuk' dalam konteks tersebut jika dilihat dari aspek referensial merujuk pada keadaan pecah dan sudah tidak berwujud lagi. Jika dilihat dari aspek diksi, kata 'gathel' tidak tergolong kata kasar. Akan tetapi, jika dilihat dari aspek pungtuasi, tuturan tersebut termasuk kasar, karena menggunakan nada tinggi dan tanda seru sebagai wujud rasa menyesal. Dilihat dari aspek konstruksi kalimat, tuturan tersebut diucapkan dengan konstruk pendek, sehingga tidak dapat memenuhi kriteria kesantunan bahasa. Begitu juga, jika dilihat dari aspek konteks, tuturan tersebut termasuk kasar, karena digunakan untuk menjelaskan rasa menyesal.

Bahasa kasar dialek Banyumasan yang berwujud kata dasar dengan referensi keadaan tertentu dengan fungsi untuk menghina orang lain.

Konteks:

Mas Kiki menghina Pak Jarwo jika Pak Jarwo itu jarang sekali mendpatkan nilai saat bermain kartu.

“Gabol rika gabolane pol!"

(Rek 10/13Agsts17/23.13)

Kata 'gabol' dalam konteks tersebut jika dilihat dari aspek referensial merujuk pada keadaan tertentu yaitu kosong, tidak mendapatkan apa-apa. Jika dilihat dari aspek diksi, kata ' $\mathrm{gabol}$ ' tergolong kata kasar. Jika dilihat dari aspek pungtuasi, tuturan tersebut termasuk kasar, karena menggunakan nada tinggi dan tanda seru sebagai wujud penghinaan kepada orang lain. Dilihat dari aspek konstruksi kalimat, tuturan tersebut diucapkan dengan konstruk pendek, sehingga tidak dapat memenuhi kriteria kesantunan bahasa. Begitu juga, jika dilihat dari aspek konteks, tuturan tersebut termasuk kasar, karena digunakan untuk menghina orang lain.

Bahasa kasar dialek Banyumasan yang berwujud kata dasar dengan referensi kegiatan tertentu dengan fungsi untuk menjelaskan rasa heran.

Konteks:

Pak Urip sedang bercerita bahwa biasanya, pekerja pribumi lebih susah diatur, tetapi ingin dibayar.

"Biasane pribumi ya iya, rata-rata pas anu ngomong jegang njaluke di bayar!”.

(Rek 19/27Agsts17/23.06)

Kata 'jegang' dalam konteks tersebut jika dilihat dari aspek referensial merujuk pada kegiatan seseorang yaitu duduk dengan kaki di atas. Kata 'jegang' dalam kehidupan masyarakat Desa Kedungreja Kabupaten Cilacap memiliki asosiasi negatif. Jika dilihat dari aspek diksi, kata 'jegang' tidak tergolong kata kasar. Akan tetapi, jika dilihat dari aspek pungtuasi, tuturan tersebut termasuk kasar, karena menggunakan nada tinggi dan tanda seru sebagai wujud rasa heran. Dilihat dari aspek konstruksi kalimat, tuturan tersebut diucapkan dengan konstruk pendek, sehingga tidak dapat memenuhi kriteria kesantunan bahasa. Begitu juga, jika dilihat dari aspek konteks, tuturan tersebut termasuk kasar, karena digunakan untuk menjelaskan rasa heran.

\section{Bahasa Kasar Berwujud Kata Berimbuhan}

Bahasa kasar dialek Banyumasan selain berwujud kata dasar, basa kasar dialek Banyumasan juga ada yang berwujud kata berimbuhan. Bahasa kasar berwujud kata berimbuhan ada tiga macam, diantaranya bahasa kasar berwujud kata berimbuhan awalan, berwujud kata berimbuhan akhiran, dan kata berimbuhan awalan dan akhiran. Selain itu ada juga bahasa kasar yang berwujud kata ulang dan tembung wancah. Bahasa kasar yang berwujud kata berimbuhan terdapat beberapa referen yang digunakan yaitu, referen keadaan seseorang, keadaan tertentu, kegiatan tertentu, nama hewan, bagian tubuh, dan jenis makanan. Dan fungsi untuk menghina orang lain, menjelaskan rasa kecewa, menjelaskan rasa jengkel, dan menjelaskan rasa heran.

Bahasa kasar yang berwujud kata ulang menggunakan beberapa referen diantaranya referen nama benda, keadaan seseorang, keadaan tertentu, dan kegiatan tertentu. Dan memiliki fungsi untuk mengungkapkan rasa kecewa, rasa jengkel, dan rasa heran. Bahasa kasar yang berwujud tembung wancah menggunakan satu referen, yaitu referen keadaan seseorang dan mempunyai fungsi untuk menjelaskan rasa kecewa. 


\section{LingTera, 5 (2), 2018 - 106}

Dimas Setiaji Prabowo, Mulyana Mulyana

Berikut ini, contoh bahasa kasar dialek Banyumasan yang berwujud kata berimbuhan awalan dengan referensi keadaan seseorang dengan fungsi untuk menghina orang lain.

Konteks:

Mas Kiki menghina Mas Edi dengan menyuruh Mas Edi melakukan kocokan kartu supaya tidak mengalihkan pembicaraan.

"Rika ngocok siki kon ngocok nang nyong, men kon ora nylimur!”.

(Rek 9/13Agsts17/23.02)

Kata 'nylimur' dalam konteks tersebut jika dilihat dari aspek referensial merujuk pada keadaan seseorang yang diberi saran, tetapi dia tidak memperhatikan. Kata 'nylimur' dalam kehidupan masyarakat Desa Kedungreja Kabupaten Cilacap memiliki asosiasi negatif. Jika dilihat dari aspek diksi, kata 'nylimur' tergolong kata kasar. Jika dilihat dari aspek pungtuasi, tuturan tersebut termasuk kasar, karena menggunakan nada tinggi dan tanda seru sebagai wujud penghinaan kepada orang lain. Dilihat dari aspek konstruksi kalimat, tuturan tersebut diucapkan dengan konstruk pendek, sehingga tidak dapat memenuhi kriteria kesantunan bahasa. Begitu juga, jika dilihat dari aspek konteks, tuturan tersebut termasuk kasar, karena digunakan untuk menghina orang lain.

Bahasa kasar dialek Banyumasan yang berwujud kata berimbuhan awalan dengan referensi kegiatan tertentu dengan fungsi untuk menjelaskan rasa kecewa.

Konteks:

Pak Manto kecewa kepada mas Hasan karena mas Hasan jika berbicara sering tidak sesuai dengan kenyataan.

"Warsan kan nggedebus!!, ngko nanaunannuna kalingane tekan kono sepi!"

(Rek 15/14Agsts17/00.59)

Kata 'nggedebus' dalam konteks tersebut jika dilihat dari aspek referensial merujuk pada kegiatan tertentu yaitu berbicara tetapi tanpa ada bukti. Kata 'nggedebus' dalam kehidupan masyarakat Desa Kedungreja Kabupaten Cilacap memiliki asosiasi negatif. Jika dilihat dari aspek diksi, kata 'nggedebus' tergolong kata kasar. Jika dilihat dari aspek pungtuasi, tuturan tersebut termasuk kasar, karena menggunakan nada tinggi dan tanda seru sebagai wujud kecewa kepada orang lain. Dilihat dari aspek konstruksi kalimat, tuturan tersebut diucapkan dengan konstruk pendek, sehingga tidak dapat memenuhi kriteria kesantunan bahasa. Begitu juga, jika dilihat dari aspek konteks, tuturan tersebut termasuk kasar, karena digunakan untuk menjelaskan rasa kecewa kepada orang lain.

Bahasa kasar dialek Banyumasan yang berwujud kata berimbuhan awalan dengan referensi kegiatan tertentu dengan fungsi untuk menghina orang lain.

Konteks:

Mas Boni menghina mas Bambang, jika ingin bisa lari cepat, jangan kebanyakan onani.

"Mulane dadi bocah Aja kakehan ngiclik! dadi mlayune banter..haha"

(Rek 25/7Sept17/20.22)

Kata 'ngiclik' dalam konteks tersebut jika dilihat dari aspek referensial merujuk pada kegiatan tertentu yaitu melakukan onani. Kata 'ngiclik' dalam kehidupan masyarakat Desa Kedungreja Kabupaten Cilacap memiliki asosiasi negatif. Jika dilihat dari aspek diksi, kata ' $n$ giclik' tergolong kata kasar. Jika dilihat dari aspek pungtuasi, tuturan tersebut termasuk kasar, karena menggunakan nada tinggi dan tanda seru sebagai wujud penghinaan kepada orang lain. Dilihat dari aspek konstruksi kalimat, tuturan tersebut diucapkan dengan konstruk pendek, sehingga tidak dapat memenuhi kriteria kesantunan bahasa. Begitu juga, jika dilihat dari aspek konteks, tuturan tersebut termasuk kasar, karena digunakan untuk menghina orang lain.

Bahasa kasar dialek Banyumasan yang berwujud kata berimbuhan awalan dengan referensi keadaan seseorang dengan fungsi untuk menghina orang lain.

Konteks:

Mas Boni heran kepada mba Sarni. Dan mengatakan bahwa sejatinya Mba Sarmi giginya maju ke depan.

"Kae bocah didelengna sue sue pancen mandan mrongol yah rengane!".

(Rek 26/ 7Sept17/ 21.02)

Kata 'mrongol' dalam konteks tersebut jika dilihat dari aspek referensial merujuk pada keadaan seseorang yaitu seseorang yang giginya agak maju. Kata 'mrongol' dalam kehidupan masyarakat Desa Kedungreja Kabupaten Cilacap memiliki asosiasi negatif. Jika dilihat dari aspek diksi, kata 'mrongol' tergolong kata kasar. Jika dilihat dari aspek pungtuasi, tuturan tersebut termasuk kasar, karena menggunakan nada tinggi dan tanda seru sebagai wujud penghinaan kepada orang lain. Dilihat dari aspek konstruksi kalimat, tuturan tersebut diucapkan dengan konstruk pendek, sehingga tidak dapat memenuhi kriteria kesantunan bahasa. Begitu juga, jika dilihat dari 
aspek konteks, tuturan tersebut termasuk kasar, karena digunakan untuk menghina orang lain.

Bahasa kasar dialek Banyumasan yang berwujud kata berimbuhan awalan dengan referensi keadaan seseorang dengan fungsi untuk menjelaskan rasa kecewa.

Konteks:

Mas Bowo heran kepada Mas Hasan karena pagipagi wajahnya sudah muram.

"Ngapa jane kae bocah isuk isuk wis mbesengut raine!".

(Rek 33/14Sept17/06.19)

Kata 'mbesengut' dalam konteks tersebut jika dilihat dari aspek referensial merujuk pada keadaan seseorang yaitu tidak mau tersenyum, wajahnya muram atau mrengut (Poerwadarminta, 1939). Kata 'mbesengut' dalam kehidupan masyarakat Desa Kedungreja Kabupaten Cilacap memiliki asosiasi negatif. Jika dilihat dari aspek diksi, kata 'mbesengut' tergolong kata kasar. Jika dilihat dari aspek pungtuasi, tuturan tersebut termasuk kasar, karena menggunakan nada tinggi dan tanda seru sebagai wujud rasa kecewa kepada orang lain. Dilihat dari aspek konstruksi kalimat, tuturan tersebut diucapkan dengan konstruk pendek, sehingga tidak dapat memenuhi kriteria kesantunan bahasa. Begitu juga, jika dilihat dari aspek konteks, tuturan tersebut termasuk kasar, karena digunakan untuk menjelaskan rasa kecewa.

Bahasa kasar dialek Banyumasan yang berwujud kata berimbuhan akhiran dengan referensi nama hewan tertentu dengan fungsi untuk menjelaskan rasa jengkel.

Konteks:

Mas Kiki merasa jengkel karena kartunya jelek, yang digambarkan seperti hewan coro.

"Corone tek buang lah!".

(Rek 11/ 13Agsts17/23.22)

Kata 'corone' dalam konteks tersebut jika dilihat dari aspek referensial merujuk pada salah satu hewan serangga yang biasa hidup ditempat kotor. Kata 'corone' dalam kehidupan masyarakat Desa Kedungreja Kabupaten Cilacap memiliki asosiasi negatif. Jika dilihat dari aspek diksi, kata 'corone' tidak tergolong kata kasar. Akan tetapi, jika dilihat dari aspek pungtuasi, tuturan tersebut termasuk kasar, karena menggunakan nada tinggi dan tanda seru sebagai wujud jengkel. Dilihat dari aspek konstruksi kalimat, tuturan tersebut diucapkan dengan konstruk pendek, sehingga tidak dapat memenuhi kriteria kesantunan bahasa. Begitu juga, jika dilihat dari aspek konteks, tuturan tersebut di atas termasuk kasar, karena digunakan untuk menjelaskan rasa jengkel.

Bahasa kasar dialek Banyumasan yang berwujud kata berimbuhan akhiran dengan referensi bagian tubuh tertentu dengan fungsi untuk menjelaskan rasa marah.

Konteks:

Pak Sarimin sedang bercerita tentang sales batu yang digunakan untuk pembakaran, Pak Sarimin bertanya, "untuk apa batu itu?" kemudian Mas Bowo menjawab "untuk melempar kepalamu" dalam hal ini sales tersebut.

A: "Lah watu gunane nggo ngapa".

B: "nggo nyrampang ndhasmu! Kaya kue".

(Rek 20/ 27Agsts17/ 23.26)

Kata 'ndhasmu' dalam konteks tersebut jika dilihat dari aspek referensial merujuk pada bagian inti dari makhluk hidup yaitu kepala. Kata 'ndhasmu' dalam kehidupan masyarakat Desa Kedungreja Kabupaten Cilacap memiliki asosiasi negatif dan tergolong tidak sopan, karena kata 'ndhas' bukan untuk menyebut kepala manusia. Jika dilihat dari aspek diksi, kata 'ndhasmu' tergolong kata kasar. Jika dilihat dari aspek pungtuasi, tuturan tersebut termasuk kasar, karena menggunakan nada tinggi dan tanda seru sebagai wujud rasa marah. Dilihat dari aspek konstruksi kalimat, tuturan tersebut diucapkan dengan konstruk pendek, sehingga tidak dapat memenuhi kriteria kesantunan bahasa. Begitu juga, jika dilihat dari aspek konteks, tuturan tersebut termasuk kasar, karena digunakan untuk menjelaskan rasa marah kepada orang lain.

Bahasa kasar dialek Banyumasan yang berwujud kata berimbuhan akhiran dengan referensi nama makanan dengan fungsi untuk menghina orang lain.

Konteks:

Pak Tarno menghina orang lain, bahwa sebenarnya orang yang terlihat kaya itu tidak mempunyai apa apa, hanya modal tempe saja dalam hal ini organ intim perempuan.

"Wong tuwane nggawane apa, tempene nggo imbuh thok!".

(Rek 18/27Agsts17/ 22.52)

Kata 'tempene' dalam konteks tersebut jika dilihat dari aspek referensial merujuk pada salah satu jenis makanan yang terbuat dari bahan kedelai yang dicampur dengan ragi. Jika dilihat dari aspek diksi, kata 'tempene' tidak tergolong kata kasar. Akan tetapi, jika dilihat dari aspek pungtuasi, tuturan tersebut termasuk kasar, karena menggunakan nada tinggi dan tanda seru sebagai wujud penghinaan kepada orang lain. 


\section{LingTera, 5 (2), 2018 - 108}

\section{Dimas Setiaji Prabowo, Mulyana Mulyana}

Dilihat dari aspek konstruksi kalimat, tuturan tersebut diucapkan dengan konstruk pendek, sehingga tidak dapat memenuhi kriteria kesantunan bahasa. Begitu juga, jika dilihat dari aspek konteks, tuturan tersebut termasuk kasar, karena digunakan untuk menghina orang lain. Kata 'tempene' dalam konteks tersebut bukan merujuk pada jenis makanan, akan tetapi merujuk pada organ intim perempuan. Dalam masyarakat Desa Kedungreja, hal tersebut dianggap tabu, akan tetapi sudah menjadi kebiasaan masyarakat penuturnya.

Bahasa kasar dialek Banyumasan yang berwujud kata berimbuhan awalan dan akhiran dengan referensi keadaan seseorang dengan fungsi untuk menghina orang lain.

Konteks:

Mas Dono menghina Mas Kiki karena tidak bisa diam, sehingga Mas Kiki terjatuh.

Kawus koe, pecicilan si..!!

(Rek 13/14Sept17/ 00.18)

Kata 'pecicilan' dalam konteks tersebut jika dilihat dari aspek referensial merujuk keadaan seseorang yang cara melihatnya ke sana ke mari tidak bisa diam. Jika dilihat dari aspek diksi, kata 'pecicilan' tergolong ke dalam kata kasar. Jika dilihat dari aspek pungtuasi, tuturan di atas termasuk kasar, karena menggunakan nada tinggi dan tanda seru sebagai wujud penghinaan kepada orang lain. Dilihat dari aspek konstruksi kalimat, tuturan tersebut diucapkan dengan konstruk pendek, sehingga tidak dapat memenuhi kriteria kesantunan bahasa. Begitu juga, jika dilihat dari aspek konteks, tuturan tersebut di atas termasuk kasar, karena digunakan untuk menghina orang lain.

Bahasa kasar dialek Banyumasan yang berwujud kata ulang dengan referensi kata benda dengan fungsi untuk menjelaskan rasa kecewa.

Konteks:

Pak Urip kecewa karena pada kenyataannya, kartunya jumlahnya ada delapan, tidak sesuai dengan jumlah yang sebenarnya.

"Wo Kartuku ana wolu, pantesan si \#\#\#\# tok. semprul-semprul!"

(Rek 7/13Agsts17/ 22.44)

Kata 'semprul-semprul' dalam konteks tersebut jika dilihat dari aspek referensial merujuk pada benda tertentu yaitu tembakau yang kualitasnya tidak baik. Kata 'semprul' dalam kehidupan masyarakat Desa Kedungreja Kabupaten Cilacap memiliki asosiasi negatif. Jika dilihat dari aspek diksi, kata 'semprul-semprul' tergolong kata kasar. Jika dilihat dari aspek pungtuasi, tuturan tersebut termasuk kasar, karena menggunakan nada tinggi dan tanda seru sebagai wujud rasa kecewa kepada orang lain. Dilihat dari aspek konstruksi kalimat, tuturan tersebut diucapkan dengan konstruk pendek, sehingga tidak dapat memenuhi kriteria kesantunan bahasa. Begitu juga, jika dilihat dari aspek konteks, tuturan tersebut termasuk kasar, karena digunakan untuk menjelaskan rasa kecewa.

Bahasa kasar dialek Banyumasan yang berwujud kata ulang dengan referensi keadaan seseorang dengan fungsi untuk menjelaskan rasa jengkel.

Konteks:

Pak Urip merasa jengkel kepada Pak Indro karena terlalu lama dan ragu-ragu dalam mengambil keputusan.

“Ayub-ayuban bae si ngapa, ora ceria temen!" (Rek 6/13Agsts17/ 22.38)

Kata 'ayub-ayuban' dalam konteks di atas jika dilihat dari aspek referensial merujuk pada keadaan seseorang yang pucat dan tidak terlihat semangat. Kata 'ayub-ayuban' dalam kehidupan masyarakat Desa Kedungreja Kabupaten Cilacap mengandung makna kurang sopan. Jika dilihat dari aspek diksi, kata 'ayub-ayuban' tergolong kata kasar. Jika dilihat dari aspek pungtuasi, tuturan tersebut termasuk kasar, karena menggunakan nada tinggi dan tanda seru sebagai wujud rasa jengkel kepada orang lain. Dilihat dari aspek konstruksi kalimat, tuturan tersebut diucapkan dengan konstruk pendek, sehingga tidak dapat memenuhi kriteria kesantunan bahasa. Begitu juga, jika dilihat dari aspek konteks, tuturan tersebut termasuk kasar, karena digunakan untuk menjelaskan rasa jengkel.

Bahasa kasar dialek Banyumasan yang berwujud kata ulang dengan referensi keadaan tertentu dengan fungsi untuk menjelaskan rasa heran.

Konteks:

Pak Indro merasa heran karena kartunya $\mathbf{J}$ semua. "J kabeh ya, bonyot-bonyot!"

(Rek 8/13Agsts17/22.54)

Kata 'bonyot-bonyot' dalam konteks tersebut jika dilihat dari aspek referensial merujuk pada keadaan rusak karena jatuh. Kata 'bonyotbonyot' dalam kehidupan masyarakat Desa Kedungreja Kabupaten Cilacap mempunyai asosiasi negatif. Jika dilihat dari aspek diksi, kata 'bonyot-bonyot' tergolong kata kasar. Jika dilihat dari aspek pungtuasi, tuturan tersebut termasuk kasar, karena menggunakan nada tinggi dan tanda seru sebagai wujud rasa heran terhadap 


\section{LingTera, 5 (2), 2018 - 109}

\section{Dimas Setiaji Prabowo, Mulyana Mulyana}

suatu keadaan. Dilihat dari aspek konstruksi kalimat, tuturan tersebut diucapkan dengan konstruk pendek, sehingga tidak dapat memenuhi kriteria kesantunan bahasa. Begitu juga, jika dilihat dari aspek konteks, tuturan tersebut termasuk kasar, karena digunakan untuk menjelaskan rasa heran.

Bahasa kasar dialek Banyumasan yang berwujud kata ulang dengan referensi kegiatan tertentu dengan fungsi untuk menjelaskan rasa heran.

Konteks:

Pak Urip bercerita pada jaman dahulu saat masih di Sumatera, ketika baru pulang dari kebun, dia melihat ada sapi sedang memakan kumbung atau kain penutup tempat tidur agar terhindar dari gigitan nyamuk

"Kumbunge Warsito mbok diethel-ethel!". (Rek 21/27Agsts17/23.44)

Kata 'diethel-ethel' jika dilihat dari aspek referensial merujuk pada keadaan dipotongpotong dengan menggunakan benda tajam. Kata 'diethel-ethel' dalam kehidupan masyarakat Desa Kedungreja Kabupaten Cilacap mengandung makna kasar. Jika dilihat dari aspek diksi, kata 'diethel-ethel' tergolong kata kasar. Jika dilihat dari aspek pungtuasi, tuturan tersebut termasuk kasar, karena menggunakan nada tinggi dan tanda seru sebagai wujud rasa heran terhadap suatu keadaan. Dilihat dari aspek konstruksi kalimat, tuturan tersebut diucapkan dengan konstruk pendek, sehingga tidak dapat memenuhi kriteria kesantunan bahasa. Begitu juga, jika dilihat dari aspek konteks, tuturan tersebut termasuk kasar, karena digunakan untuk menjelaskan rasa heran.

Bahasa kasar dialek Banyumasan yang berwujud tembung wancah dengan referensi keadaan seseorang dengan fungsi untuk menjelaskan rasa kecewa.

Konteks:

Mas Bowo merasa kecewa karena pemainnya ketika tinggal menendang bola, tetapi justru terlalu lama, sehingga lawan sudah menutup ruang tembaknya.

"Ah, ngapa sih wir..!"

(Rek 5/5Agsts17/ 00.03)

Kata 'wir' berasal dari kata dasar 'dawir' yang dipenggal menjadi 'wir'. Kata 'wir' jika dilihat dari aspek referensial merujuk pada keadaan seseorang yang mempunyai bibir tebal. Kata 'wir' dalam kehidupan masyarakat Desa Kedungreja Kabupaten Cilacap memiliki asosiasi negatif. Jika dilihat dari aspek diksi, kata 'wir' tergolong kata kasar. Jika dilihat dari aspek pungtuasi, tuturan tersebut termasuk kasar, karena menggunakan nada tinggi dan tanda seru sebagai wujud kecewa kepada orang lain. Dilihat dari aspek konstruksi kalimat, tuturan tersebut diucapkan dengan konstruk pendek, sehingga tidak dapat memenuhi kriteria kesantunan bahasa. Begitu juga, jika dilihat dari aspek konteks, tuturan tersebut termasuk kasar, karena digunakan untuk menjelaskan rasa kecewa.

\section{Bahasa Kasar Berwujud Frasa}

Bahasa kasar dialek Banyumasan yang berwujud frasa diantaranya terdapat beberapa referen yang digunakan yaitu referen bagian tubuh, benda tertentu, referen nama hewan, dan referen keadaan seseorang Dan fungsi untuk menghina orang lain.

Bahasa kasar dialek Banyumasan yang berwujud frasa dengan referensi bagian tubuh dengan fungsi untuk menghina orang lain seperti konteks di bawah ini.

Konteks:

Mas Bowo sedang bercerita dengan temannya yang bernama Iqbal, kemudian bertanya bahwa teman kita yang bernama anggit dulu dipanggil dengan sebutan 'ndhas bogo'.

"Anggit mbok sing mbiyen diundange ndhas bogo ya bal!"

(Rek 6/13Agsts17/22.38)

Frasa 'ndhas bogo' jika dilihat dari aspek referensial merujuk pada salah satu bagian tubuh ikan, yaitu kepala. Jika dilihat dari aspek diksi, frasa 'ndhas bogo' tidak tergolong frasa kasar. Akan tetapi, jika dilihat dari aspek pungtuasi, tuturan tersebut termasuk kasar, karena menggunakan nada tinggi dan tanda seru sebagai wujud penghinaan kepada orang lain. Dilihat dari aspek konstruksi kalimat, tuturan tersebut diucapkan dengan konstruk pendek, sehingga tidak dapat memenuhi kriteria kesantunan bahasa. Begitu juga, jika dilihat dari aspek konteks, frasa 'ndhas bogo' digunakan untuk nama panggilan terhadap manusia, sedangkan dalam masyarakat Jawa, 'ndhas' hanya digunakan untuk menyebut hewan atau sejenisnya, sehingga tuturan tersebut termasuk kasar, karena digunakan untuk menghina orang lain. Bahasa kasar dialek Banyumasan yang berwujud frasa dengan referensi benda tertentu dengan fungsi untuk menghina orang lain seperti konteks berikut.

Konteks:

Mas Bowo merasa heran kepada pemain bola di televisi, karena kulitnya sangat hitam sehingga menyebabkan pemain tersebut 
yang terlihat hanya giginya saja.

"Kae koh pemain bal irenge kaya silit ketel ya!.. Kur keton untune".

(Rek 29/9Sept17/ 01.30)

Frasa 'silit ketel' jika dilihat dari aspek referensial merujuk pada nama benda tertentu yaitu bagian panci sisi bawah yang biasanya hitam karena sisa pembakaran. Jika dilihat dari aspek diksi, frasa 'silit ketel' tidak tergolong frasa kasar. Akan tetapi, jika dilihat dari aspek pungtuasi, tuturan tersebut termasuk kasar, karena menggunakan nada tinggi dan tanda seru sebagai wujud penghinaan kepada orang lain. Dilihat dari aspek konstruksi kalimat, tuturan tersebut diucapkan dengan konstruk pendek, sehingga tidak dapat memenuhi kriteria kesantunan bahasa. Begitu juga, jika dilihat dari aspek konteks, tuturan tersebut termasuk rasis yang sebenarnya tidak diperbolehkan dalam aturan di tempat manapun. Maka dari itu, tuturan tersebut termasuk kasar, karena digunakan untuk menghina orang lain.

Bahasa kasar dialek Banyumasan yang berwujud frasa dengan referensi keadaan seseorang dengan fungsi untuk menghina orang lain, seperti konteks berikut ini.

Konteks:

Pak Urip sedang bercerita tentang simbahsimbah yang meminta sumbangan, Pak Urip tidak percaya bahwa sumbangan tersebut akan diberikan kepada orang yang membutuhkan.

"Ora mungkin saben dinten mider-mider ngantek ireng ndhetheng kaya kae nggo muliakna wong".

(Rek 20/27Agsts17/ 23.26)

Frasa 'ireng ndhetheng' jika dilihat dari aspek referensial merujuk pada keadaan seseorang dengan warna kulit yang hitam. Jika dilihat dari aspek diksi, frasa 'ireng ndhetheng' tergolong frasa kasar. Jika dilihat dari aspek pungtuasi, tuturan tersebut termasuk kasar, karena menggunakan nada tinggi dan tanda seru sebagai wujud penghinaan kepada orang lain. Dilihat dari aspek konstruksi kalimat, tuturan tersebut diucapkan dengan konstruk pendek, sehingga tidak dapat memenuhi kriteria kesantunan bahasa. Begitu juga, jika dilihat dari aspek konteks, tuturan tersebut termasuk kasar, karena digunakan untuk menghina orang lain.

\section{SIMPULAN}

Bahasa kasar dialek Banyumasan di Desa Kedungreja Kabupaten Cilacap memiliki tiga wujud, yaitu bahasa kasar berwujud kata dasar, bahasa kasar berwujud kata berimbuhan, dan bahasa kasar berwujud frase. Bahasa kasar berwujud kata dasar berupa referen nama hewan, referen jenis makanan, referen pekerjaan, referen kotoran, referen bagian tubuh, referen keadaan seseorang, referen keadaan tertentu, dan referen kegiatan tertentu. Bahas kasar ini berfungsi untuk menjelaskan rasa marah, rasa kecewa, rasa heran, menghina, rasa menyesal, dan rasa jengkel.

Bahasa kasar berwujud kata berimbuhan terdiri atas bahasa kasar berwujud kata berimbuhan awalan, berimbuhan akhiran, dan berimbuhan awalan dan akhiran. Selain itu ada juga berwujud kata ulang dan tembung wancah. Bahasa kasar yang berwujud kata berimbuhan terdapat beberapa referen yang digunakan yaitu, referen keadaan seseorang, referen keadaan tertentu, referen kegiatan tertentu, referen nama hewan, referen bagian tubuh, dan referen jenis makanan. Dan fungsi untuk menghina orang lain, menjelaskan rasa kecewa, menjelaskan rasa jengkel, dan menjelaskan rasa heran. Bahasa kasar yang berwujud kata ulang menggunakan beberapa referen diantaranya, referen nama benda, referen keadaan seseorang, referen keadaan tertentu, dan kegiatan tertentu. Dan memiliki fungsi untuk menjelaskan rasa kecewa, rasa jengkel, dan rasa heran. Bahasa kasar yang berwujud tembung wancah menggunakan satu referen, yaitu referen keadaan seseorang dan mempunyai fungsi untuk menjelaskan rasa kecewa.

Bahasa kasar dialek Banyumasan yang berwujud frasa diantaranya terdapat beberapa referen yang digunakan yaitu referen bagian tubuh, referen benda tertentu, referen nama hewan, dan referen keadaan seseorang Dan fungsi untuk menghina orang lain.

\section{DAFTAR PUSTAKA}

Devianty, R. (2017). Bahasa sebagai cermin kebudayaan. Jurnal Tarbiyah, 24(2). https://doi.org/10.30829/TAR.V24I2.167

Dulock, H. L. (1993). Research design: Descriptive research. Journal of Pediatric Oncology Nursing, 10(4), 154-157. https://doi.org/10.1177/104345429301000 406

Effendy, N. (1998). Dasar-dasar keperawatan kesehatan masyarakat. EGC.

Junaidi, J., Yani, J., \& Rismayeti, R. (2016). Variasi inovasi leksikal bahasa melayu Riau di Kecamatan Pulau Merbau. Jurnal Pustaka Budaya, 3(1), 1-16. Retrieved from 


\section{LingTera, 5 (2), 2018 - 111}

Dimas Setiaji Prabowo, Mulyana Mulyana

https://journal.unilak.ac.id/index.php/pb/a rticle/view/582

Moleong, L. J. (2013). Metodologi penelitian kualitatif (Ed. Rev.). Bandung: PT Remaja Rosdakarya. https://doi.org/2010

Noble, H., \& Smith, J. (2014). Qualitative data analysis: A practical example. EvidenceBased Nursing, 17(1), 2-3. https://doi.org/10.1136/eb-2013-101603

Poerwadarminta, W. J. S. (1939). Baoesastra Djawa. JB Wolters.

Sudaryanto. (1993). Metode dan aneka teknik analisis bahasa: pengantar penelitian wahana kebudayaan secara linguistis. Duta Wacana University Press.

Suhendi, E. T. (2017). Berbahasa, berpikir, dan peran pendidikan bahasa. In Proceedings Education and Language International Conference (Vol. 1). Retrieved from http://jurnal.unissula.ac.id/index.php/ELI C/article/view/1243

Suherman, A. (2012). Perubahan fonologis kata- kata serapan bahasa Sunda dari Bahasa Arab: Studi kasus pada masyarakat Sunda di Jawa Barat, Indonesia. Sosiohumanika: Jurnal Pendidikan Sains Sosial Dan Kemanusiaan., 5(1). Retrieved from https://journals.mindamas.com/index.php/ sosiohumanika/article/view/456/0

Uhlenbeck, E. M. (1964). A critical survey of studies on the languages of Java and Madura: Bibliographical series 7. Springer Netherlands.

Wicaksono, L. (2016). Bahasa dalam komunikasi pembelajaran. Jurnal Pembelajaran Prospektif, 1(2). Retrieved from http://jurnal.untan.ac.id/index.php/lp3m/ar ticle/view/19211

Yuliawan, T. (2016). Pemerolehan bahasa Indonesia pada anak usia 2-5 tahun di perumahan air dingin Marpoyan Pekanbaru Riau. GERAM (Gerakan Aktif Menulis), 4(3), 91-99. Retrieved from http://www.journal.uir.ac.id/index.php/G RM/article/view/1147 